\title{
Floral Resource Partitioning between Centris (Heterocentris) analis (Fabricius, 1804) and Centris (Heterocentris) terminata Smith, 1874 (Hymenoptera, Apidae, Centridini), in an Urban Fragment of the Atlantic Forest
}

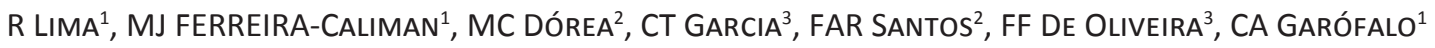 \\ 1 - Universidade de São Paulo (USP), Faculdade de Filosofia, Ciências e Letras de Ribeirão Preto, São Paulo, Brazil \\ 2 - Universidade Estadual de Feira de Santana (UEFS), Bahia, Brazil \\ 3 - Universidade Federal da Bahia (UFBA), Salvador-BA, Brazil
}

\section{Article History}

Edited by

Celso F. Martins, UFPB, Brazil

Received 21 March 2017

Initial acceptance 10 May 2017

Final acceptance 09 June 2017

Publication date 17 October 2017

\section{Keywords}

Pollen analysis, oil-collecting bees, solitary bees, trophic niche, urban areas.

\section{Corresponding author}

Reinanda Lima

USP/Faculdade de Filosofia, Ciências e

Letras de Ribeirão Preto

Av. Bandeirantes no 3900, CEP 14040-901

Ribeirão Preto, São Paulo, Brasil.

E-Mail: reinanda-09lima@usp.br

\begin{abstract}
The knowledge on plant species used for the collection of floral resources is crucial to understanding interactions between plants and bees. The aim of the present study was to identify floral resources used by Centris analis and Centris terminata to provision brood cells and determine the niche breadth and overlap of these two species in a fragment of the Atlantic Forest in Brazil. This study was conducted at the Universidade Federal da Bahia and Parque Zoobotânico Getúlio Vargas, both of which are located in urban areas of the city of Salvador in the state of Bahia. In general, twelve and eight pollen types were identified in $C$. analis and $C$. terminata nests, respectively. The most frequent pollen types were from species of Malpighiaceae and Fabaceae. A larger trophic niche breadth was found in the Parque Zoobotânico Getúlio Vargas for $C$. analis and in the Universidade Federal da Bahia for $C$. terminata. Pianka's index demonstrated trophic niche overlap between $C$. analis and C. terminata, which was greater in the Parque Zoobotânico Getúlio Vargas. This study is the first to provide data on plants used as food sources by species of the genus Centris in a fragment of the Atlantic Forest situated within urban areas.
\end{abstract}

\section{Introduction}

Bees of the genus Centris Fabricius, 1804 are widely distributed in the Americas (Michener, 2007). Centris analis (Fabricius, 1804) occurs from Mexico to Brazil and Centris terminata Smith, 1874 occurs from Ecuador to Brazil (Moure et al., 2012). These two species belong to the subgenus Heterocentris Cockerell, 1899. Females of $C$. analis and $C$. terminata build nests in preexisting cavities, such as the abandoned nests of other bees or wasps, galleries dug by other insects and trap-nests (Michener \& Lange, 1958; Coville et al., 1983).

As occurs with other bees, Centris females visit flowers for the purpose of collecting pollen and nectar to supply their own energy needs and provision brood cells. These bees also use the floral oil to feed larvae and/or build nests
(Vogel, 1974; Neff \& Simpson, 1981; Vieira-de-Jesus \& Garófalo, 2000; Alves-dos-Santos et al., 2007). Species of the genus are efficient pollinators of native and cultivated plants with economic importance as, for example, $C$. analis being a effective pollinators of Malpighia emarginata Sessé and Moc ex DC (Vilhena \& Augusto, 2007; Oliveira \& Schlindwein, 2009), Byrsonima sericea D.C (Ramalho \& Silva, 2002) and C. terminata being an known pollinator of Passiflora alata Curtis (Mello et al., 2014).

In general, Centris bees are considered generalists due to the behavior of collecting resources from different botanical families (Quiroz-Garcia et al., 2001; Aguiar et al., 2003; Dórea et al., 2010; Santos et al., 2013). However, according to Gonçalves et al. (2012), females of Centris tarsata showed an oligolectic behavior, collecting pollen from Solanaceae species for larval provisioning in a region of southern Brazil. 
Studies involving the analysis of residual pollen from Centris nests show that species of the family Malpighiaceae are the most frequently used, followed by Fabaceae and Solanaceae. Several studies showed the preferences of pollen types used by females of Centris to feed their larvae, as well, Centris flavifrons (Fabricius, 1775) (Rêgo et al., 2006), Centris maranhensis Ducke, 1910 (Ramos et al., 2007), Centris caxienses (Ducke, 1907) (Ribeiro et al., 2008), Centris tarsata Smith, 1874 (Mendes \& Rêgo, 2007; Dórea et al., 2009; Gonçalves et al., 2012; Cruz et al., 2015), Centris analis (Fabricius, 1804) (Quiróz- Garcia et al., 2001; Oliveira \& Schlindwein, 2009; Roubik \& Villanueva-Gutiérrez, 2009; Dórea et al., 2010; Rabelo et al., 2012; Santos et al., 2013), Centris trigonoides Lepeletier, 1841 (Quiróz- Garcia et al., 2001; Dórea et al., 2013) and Centris flavofasciata Friese, 1899 (Quiroz-Garcia \& de la Arreguin-Sánchez, 2006). The number of species investigated thus far is less than $10 \%$ of the total of the genus known by science. For $C$. terminata (one of the two species analyzed in the present study), there are no previous records of the resources collected by females to provision nests.

Direct observations in the field can provide information on resource utilization by Centris bees. Moreover, an analysis of pollen stored in nests enables a detailed account of the number of plant species used as resources (Cane \& Sipes, 2006). Knowledge of food sources is essential to understanding associations among bees and plants and provides valuable information for the development of management and conservation plans. Therefore, the aim of the present study was to identify floral resources used by $C$. analis and $C$. terminata females to provision brood cells and assess the niche breadth and overlap of these species in an urban fragment of the Atlantic Forest in the city of Salvador, Brazil.

\section{Material and Methods}

Study area

This study was carried out in an urban fragment of the Atlantic Forest in the city of Salvador, state of Bahia, Brazil $\left(13^{\circ} 01^{\prime} \mathrm{S}\right.$ and $\left.38^{\circ} 31^{\prime} \mathrm{W}\right)$. Based on the Köppen typology, the climate in Salvador is Af - tropical hot and wet. Mean annual temperature is $25.3^{\circ} \mathrm{C}$ and mean annual rainfall is $1800 \mathrm{~mm}$ (Conder, 1994). The study sites were the Parque Zoobotânico Getúlio Vargas (PZBGV) and the campus of Universidade Federal da Bahia (UFBA). The PZBGV covers a green area of about $240,000 \mathrm{~m}^{2}$ and is structurally characterized by sparse tree-shrub vegetation, with several species of Fabaceae, Solanaceae, Malpighiaceae, Myrtaceae, Bignoniaceae and Melastomataceae (N. Roque, personal information). The UFBA campus occupies an area of $302,000 \mathrm{~m}^{2}$ and is composed of small fragments of heterogeneous herbaceous vegetation, with a predominance of grasses and secondary shrubbyarboreal Atlantic Forest. Several species of botanical families are scattered around the campus, such as Anacardiaceae, Arecaceae, Bignoniaceae, Fabaceae, Malvaceae, Malpighiaceae, Meliaceae, Moraceae and Myrtaceae (Carvalho et al., 2007).
There are also squares, buildings and gardens with ornamental plants (Carvalho et al., 2007).

\section{Data collection and pollen analysis}

The pollen samples were obtained from nests established in trap-nests. The trap-nests were installed in the field in April 2014 and inspected once a month from May 2014 to April 2015. Once established, the closed nests were taken to the laboratory and stored at a room temperature until the emergence of individuals.

The pollen samples of $C$. analis were obtained from 53 nests $(\mathrm{UFBA}=27$ and $\mathrm{PZBGV}=26)$ and those of $C$. terminata from 20 nests $(\mathrm{UFBA}=7$ and $\mathrm{PZBGV}=13)$. All $C$. analis nests were established in black cardboard trap-nests with inner diameters of 0.6 and $0.8 \mathrm{~cm}$. The nests of $C$. terminata were established in bamboo canes $(\mathrm{n}=11$ nests) with inner diameters of 0.6 and $1.0 \mathrm{~cm}$, and wooden blocks ( $\mathrm{n}=9$ nests) with an inner diameter of $1.0 \mathrm{~cm}$.

After the emergence of the individuals, residual pollen from the inner wall of the brood cells was removed for analysis. In brood cells containing dead eggs or larvae, all food present in the cell was collected for analysis. The pollen material of each nest was transferred to test tubes containing $50 \mathrm{~mL}$ of an aqueous ethanol solution (70\%). After 24 hours, the ethanol was discarded and the samples were placed in $4 \mathrm{~mL}$ of glacial acetic acid for 24 hours (Silva et al., 2010). Subsequently, the pollen material was submitted to the acetolysis process following the method described by Erdtman (1960). The pollen was then put in an aqueous glycerine solution (50\%). After 24 hours, small amounts of pollen were removed with cubes of glycerine jelly for the preparation of three microscopic slides per nest. Photomicrographs were taken and pollen types were identified by comparisons with the specialized bibliography and reference slides from the collection of the Plant Micromorphology Laboratory, Universidade Estadual de Feira de Santana. Quantitative analyses were based on the first 1000 pollen grains counted per sample, as proposed by Vergeron (1964).

\section{Data analysis}

Based on Santos et al. (2013), the monthly relative frequency $\left(\mathrm{RF}_{\mathrm{m}}\right)$ and total relative frequency $\left(\mathrm{RF}_{\mathrm{t}}\right)$ of each pollen type were calculated by the ratio between the number of grains of each registered pollen type (monthly and during the nesting period) and the total number of grains counted each month and during the entire nesting period, respectively.

Trophic niche breadth was calculated using Shannon's index (H') (Pielou, 1975) and compared using Hutcheson's t-test (Zar, 1984). Pielou's index (J') (Pielou, 1966) was used to calculate the evenness of the use of floral resources by $C$. analis and C. terminata. Pianka's index $\left(\mathrm{O}_{\mathrm{jk}}\right)$ (Pianka, 1973) was used to calculate trophic niche overlap between $C$. analis and C. terminata:

$$
\mathbf{O}_{j k}=\frac{\sum_{i}^{n} p_{i j p_{i k}}}{\sqrt{\sum_{i}^{n} p i j^{2} \sum_{i}^{n} p_{i k}^{2}}}
$$


where $O_{j k}=$ corresponds to the measure of overlap of the trophic niche of Pianka between species $j$ and species $k ; p_{i j}=$ is the occurrence of pollen type $i$ in the diet of the bee species $j ; p_{i k}=$ is the occurrence of pollen type $j$ in the diet of the bee species $k$ and $\sum=$ is sum that considers the values related to pollen type 1 to pollen type $\mathrm{S}$ (richness). The index varies between 0 (no overlap) and 1 (complete overlap). The analysis of diet breadth was performed using the PAST statistical software, version 2.17 (Hammer et al., 2001). The analysis of trophic niche overlap was performed using the R statistical software, version 2.01 (R Development Core Team, 2011).
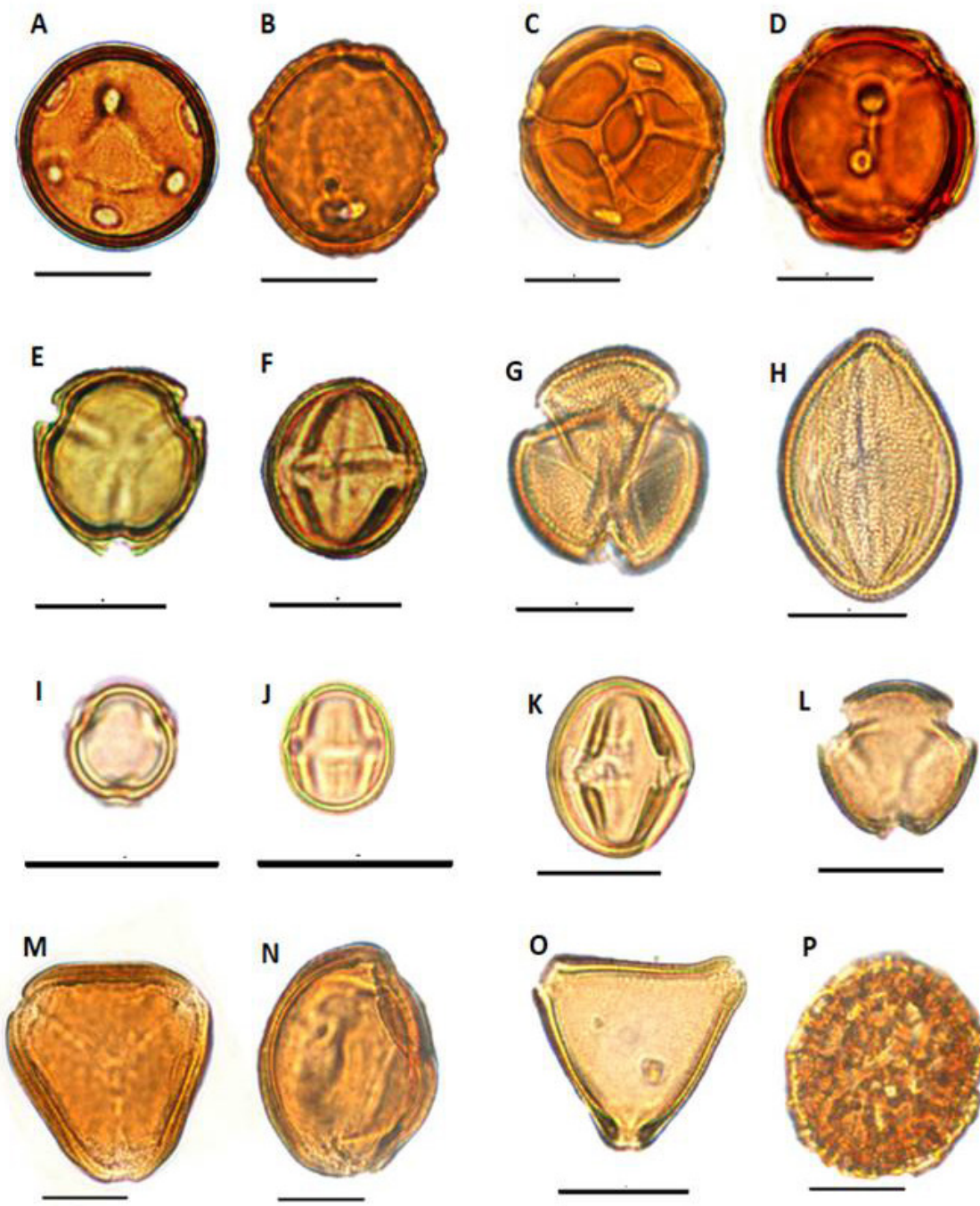

larval food sources per month in both studied areas. The nesting activity of the females was registered to the months of May, October, November, and December (2014), January, February, March and April (2015). Centris analis females used 12 pollen types belonging to seven botanical families to provision nests established at UFBA (Table 1 and Figure 1A-S), whereas 11 pollen types belonging to six botanical
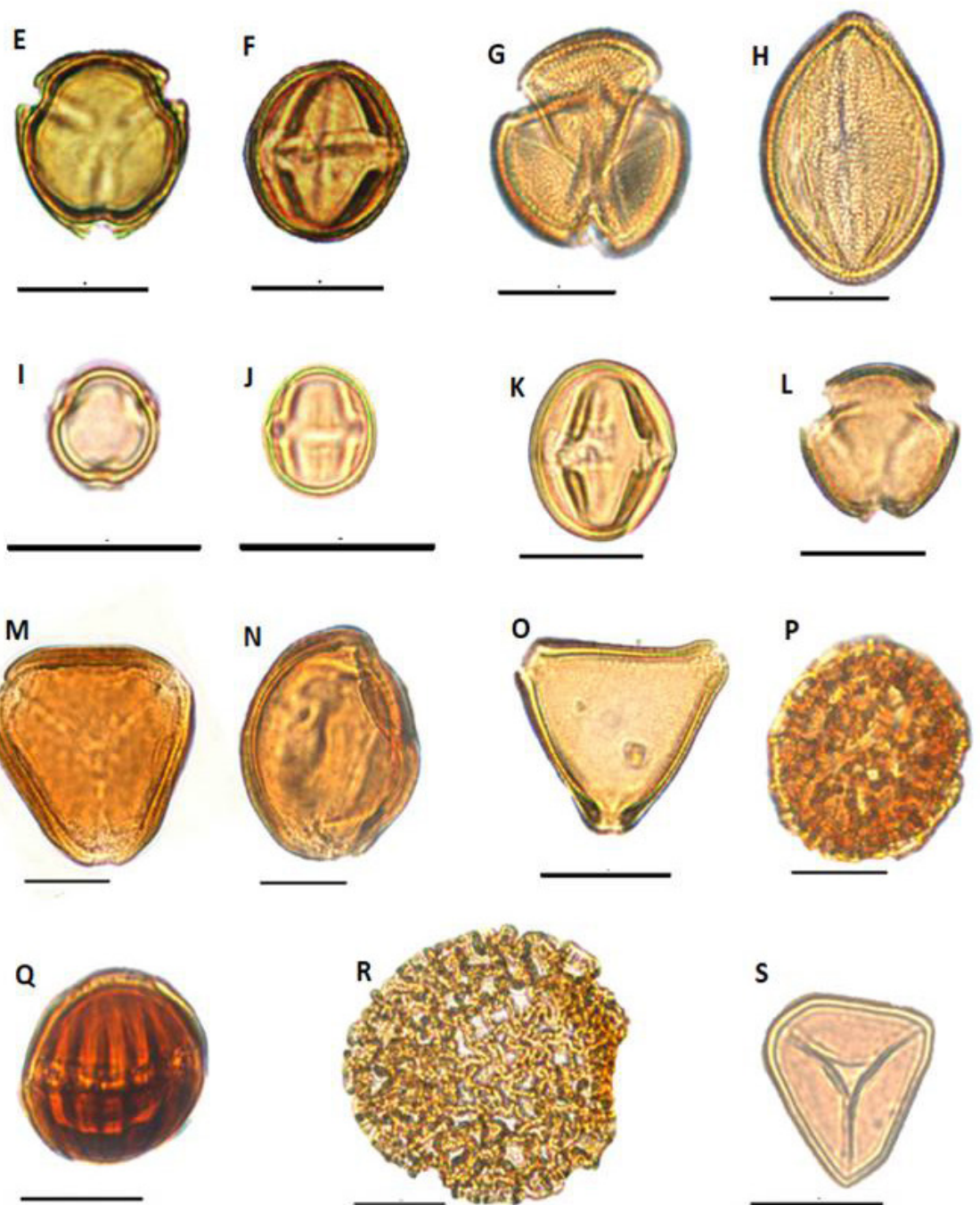

Fig 1. Pollen types found in nests of Centris analis (Fabricius, 1804) and Centris terminata Smith, 1874 sampled from urban fragment of Atlantic Forest in Salvador, Bahia. A-B: Malpighia emarginata (Malpighiaceae). C-D: Stigmaphyllon cavernulosum (Malpighiaceae). E-F: Cestrum axillare (Solanaceae). G-H: Handroanthus chrysotrichus (Bignoniaceae). I-J: Byrsonima sericea (Malpighiaceae). K-L: Aeschynomene paucifolia (Fabaceae). M-N: Dioclea grandiflora (Fabaceae).O: Serjania type (Sapindaceae). P: Delonix regia (Fabaceae). Q: Securidaca diversifolia (Polygalaceae). R: Amphilophium crucigerum (Bignoniaceae). S: Elaeis guineensis (Arecaceae). $($ Bar scale $=25 \mu \mathrm{m})$. 


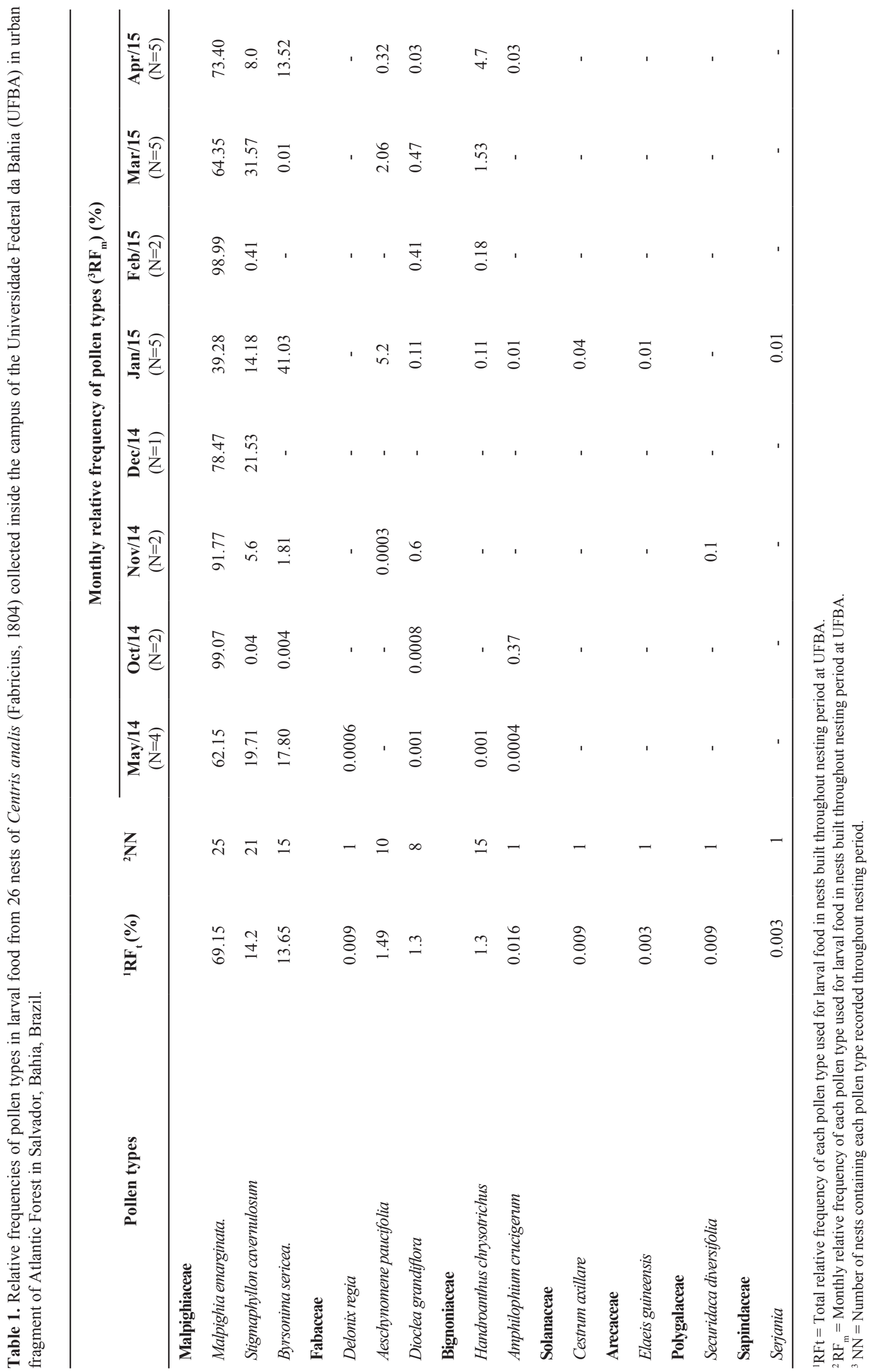


families were identified from nests built at PZBGV (Table 2 and Figure 1 A-P, R-S).

Pollen types from the family Malpighiaceae were the most abundant types used by $C$. analis females in both study areas. At UFBA, the most common pollen type was Malpighia emarginata, with frequencies varying from 39 to $99 \%$, in the months of May, October, November, December 2014 and January, February, March and April 2015 (Table 1). Also, Byrsonima sericea. showed high frequencies (41\%) in January 2015. At PZBGV, the pollen type with the highest relative frequency was Stigmaphyllon cavernulosum in nests of May (51.65\%) and December 2014 (89.70\%). Byrsonima sericea was most frequent pollen in the nests of January 2015 (72.63\%). Malpighiae emarginata pollen was the most abundant source in the nests of February, March and April 2015 (Table 2).

The trophic niche breadth of $C$. analis was significantly higher for nests established at PZBGV $\left(\mathrm{H}^{\prime}{ }_{\text {PZBGV }}=1.32\right)$ than for nests built at UFBA $\left(\mathrm{H}_{\text {UFBA }}^{\prime}=0.94\right)(\mathrm{t}=-4.16 ; \mathrm{p}>0.05)$. The equitability indices were J'UFBA $=0.21$ and $\mathrm{J}^{\prime} \mathrm{PZBGV}=0.36$ ). Pollen types used by Centris terminata

Table 2. Relative frequencies of pollen types in larval food from 27 nests of Centris analis (Fabricius, 1804) collected from Parque Zoobotânico Getúlio Vargas (PZBGV) in urban fragment of Atlantic Forest in Salvador, Bahia, Brazil.

\begin{tabular}{|c|c|c|c|c|c|c|c|c|}
\hline \multirow[b]{2}{*}{ Pollen types } & \multirow[b]{2}{*}{$\begin{array}{l}{ }^{1} \mathrm{RF}_{\mathrm{t}} \\
(\%)\end{array}$} & \multirow[b]{2}{*}{${ }^{2} \mathbf{N N}$} & \multicolumn{6}{|c|}{ Monthly relative frequency of pollen types $\left({ }^{3} R_{\mathrm{m}}\right)(\%)$} \\
\hline & & & $\begin{array}{c}\text { May/14 } \\
(\mathrm{N}=2)\end{array}$ & $\begin{array}{c}\text { Dec/14 } \\
(\mathrm{N}=1)\end{array}$ & $\begin{array}{c}\text { Jan/15 } \\
(\mathrm{N}=5)\end{array}$ & $\begin{array}{c}\text { Feb/15 } \\
(\mathrm{N}=9)\end{array}$ & $\begin{array}{c}\text { Mar/15 } \\
(\mathrm{N}=5)\end{array}$ & $\begin{array}{c}\text { Apr/15 } \\
(\mathrm{N}=5)\end{array}$ \\
\hline \multicolumn{9}{|l|}{ Malpighiaceae } \\
\hline Malpighia emarginata & 25.65 & 20 & 44.58 & - & 10.52 & 32.63 & 60.23 & 69.74 \\
\hline Stigmaphyllon cavernulosum & 25.71 & 24 & 51.65 & 89.70 & 0.83 & 27.16 & 36.34 & 7.06 \\
\hline Byrsonima sericea & 38.81 & 19 & 0.60 & 0.27 & 72.63 & 32.45 & 0.19 & 19.98 \\
\hline \multicolumn{9}{|l|}{ Fabaceae } \\
\hline Delonix regia & 0.02 & 4 & - & - & - & 0.03 & 0.08 & - \\
\hline Aeschynomene paucifolia & 6.45 & 14 & - & 0.90 & 15.06 & 3.770 & 2.03 & 0.86 \\
\hline Dioclea grandiflora & 3.25 & 16 & 2.73 & 9.13 & 0.96 & 4.02 & 0.08 & 1.80 \\
\hline \multicolumn{9}{|l|}{ Bignoniaceae } \\
\hline Handroanthus chrysotrichus & 0.04 & 5 & 0.35 & - & - & 0.009 & 0.82 & 0.54 \\
\hline Amphilophium crucigerum & 0.04 & 4 & - & - & - & - & 0.21 & 0.01 \\
\hline \multicolumn{9}{|l|}{ Solanaceae } \\
\hline Cestrum axillare & 0.01 & 5 & 0.04 & - & - & 0.009 & - & 0.01 \\
\hline \multicolumn{9}{|l|}{ Arecaceae } \\
\hline Elaeis guineensis & 0.01 & 1 & 0.04 & - & - & - & - & - \\
\hline \multicolumn{9}{|l|}{ Sapindaceae } \\
\hline Serjania type & 0.01 & 1 & - & - & - & - & - & 0.01 \\
\hline
\end{tabular}

Nesting activities of $C$. terminata were restricted to the months of May (2014), January, February, and March (2015). At UFBA, the females used seven pollen types belonging to four botanical families (Table 3 and Figure $1 \mathrm{~A}-\mathrm{N}$ ) while at $\mathrm{PZBGV}$, they used six pollen types belonging to three botanical families (Table 4 and Figure 1 A-D, I-N, R).

Pollen types from the families Malpighiaceae and Fabaceae were the most abundant in $C$. terminata nests in both areas. At UFBA, the pollen with the highest monthly relative frequency was M. emarginata $(94.87 \%)$, in May 2014, followed by Aeschynomene paucifolia (73.58\%), in February 2015, and B. sericea (64.05\%), in March 2015 (Table 3). At PZBGV, the pollen type with the highest relative frequency was B. sericea $(61.37 \%)$, in January 2015 , and M. emarginata type (38.02\%) was the most common source in the nests of March 2015 (Table 4).

No significant difference $(\mathrm{t}=1.39 ; \mathrm{p}<0.05)$ was found between the trophic niche breadth of nests established at UFBA $\left(\mathrm{H}^{\prime}{ }_{\text {UFBA }}=1.21\right)$ and those established at PZBGV $\left(\mathrm{H}_{\text {PZBGV }}{ }=1.07\right)$. The equitability indices were $\mathrm{J}_{\text {UFBA }}^{\prime}=0.48$ and $\mathrm{J}^{\prime}{ }_{\text {PZBGV }}=0.42$.

\section{Trophic niche overlap between Centris analis and Centris} terminata

Among the 12 pollen types found in the nests of $C$. analis and C. terminata, eight types were common to both species (Tables 1-4). Four pollen types were exclusively found in C. analis nests: Delonix regia, Securidaca diversifolia, 
Table 3. Relative frequencies of pollen types in the larval food from 7 nests of Centris terminata Smith, 1874 collected from campus of Universidade Federal daBahia (UFBA) in urban fragment of Atlantic Forest in Salvador, Bahia, Brazil.

\begin{tabular}{|c|c|c|c|c|c|}
\hline \multirow[b]{2}{*}{ Pollen types } & \multirow{2}{*}{$\begin{array}{l}{ }^{1} \mathrm{RF}_{\mathrm{t}} \\
(\%)\end{array}$} & \multirow[b]{2}{*}{${ }^{2} \mathbf{N N}$} & \multicolumn{3}{|c|}{ Monthly relative frequency of pollen types $\left({ }^{3} R_{\mathrm{m}}\right)(\%)$} \\
\hline & & & $\begin{array}{c}\text { May/14 } \\
(\mathrm{N}=1)\end{array}$ & $\begin{array}{c}\text { Feb/15 } \\
(\mathrm{N}=5)\end{array}$ & $\begin{array}{c}\text { Mar/15 } \\
(\mathrm{N}=1)\end{array}$ \\
\hline \multicolumn{6}{|l|}{ Malpighiaceae } \\
\hline Malpighia emarginata & 23.29 & 5 & 94.87 & 17.37 & - \\
\hline Byrsonima sericea & 13.5 & 5 & 0.17 & 2.88 & 64.05 \\
\hline \multicolumn{6}{|l|}{ Fabaceae } \\
\hline Aeschynomene paucifolia & 66.12 & 7 & 0.17 & 73.58 & 0.07 \\
\hline Dioclea grandiflora & 1.24 & 3 & - & 1.39 & 3.17 \\
\hline \multicolumn{6}{|l|}{ Bignoniaceae } \\
\hline
\end{tabular}

${ }^{1} \mathrm{RF}_{\mathrm{t}}=$ Total relative frequency of each pollen type used for larval food in nests built throughout nesting period at UFBA.

${ }^{2} \mathrm{RF}_{\mathrm{m}}^{\mathrm{t}}=$ Monthly relative frequency of each pollen type used for larval food in nests built throughout nesting period at UFBA.

${ }^{3} \mathrm{NN}=$ Number of nests containing each pollen type recorded throughout nesting period.

Elaeis guineensis. And Serjania type. Based on the similarity of the use of the pollen types, trophic niche overlap between $C$. analis and C. terminata was $\mathrm{Ojk}=0.03$ at UFBA and Ojk=0.99 at PZBGV.

\section{Discussion}

The present study showed that the most frequent pollen types collected by females of $C$. analis and $C$. terminata in the urban fragment of the Atlantic Forest were M. emarginata, $B$. sericea, S. cavernulosum and A. paucifolia, which indicates the importance of these species as sources of food for immature bees. The association between species of the tribe Centridini and species of Malpighiaceae results in a very specialized mutualism, with flowers depending on bees for pollination and the larvae of those bees depending on pollen and flower oils for nourishment (Vogel, 1974), although some species of bees use nectar rather than floral oils (Aguiar \& Garófalo, 2004). Moreover, these bees use the oil as construction material for nests (Vogel, 1974; Vinson \& Frankie, 2000; Vieira-de-Jesus \& Garófalo, 2000; Aguiar et al., 2003; Dórea et al., 2009, 2010ab, 2013; Rabelo et al., 2012). Studies performed in different biomes and orchards report these same three genera of Malpighiaceae as the main sources of pollen and oil for many species of Centris (Gaglianone, 2001; Ramalho \& Silva, 2002; Rêgo et al., 2006; Vilhena \& Augusto, 2007; Ramos et al., 2007; Mendes \& Rêgo, 2007; Dórea et al., 2009, 2013; Mello et al., 2013 and references therein; Santos et al.,2013

Table 4. Relative frequencies of pollen types in larval food from 13 nests of Centris terminata Smith, 1874 collected from Parque Zoobotânico Getúlio (PZBGV) in urban fragment of Atlantic Forest in Salvador, Bahia, Brazil.

\begin{tabular}{|c|c|c|c|c|}
\hline \multirow[b]{2}{*}{ Pollen types } & \multirow[b]{2}{*}{$\begin{array}{l}{ }^{1} \mathbf{R F}_{\mathrm{t}} \\
(\%)\end{array}$} & \multirow[b]{2}{*}{${ }^{2} \mathbf{N N}$} & \multicolumn{2}{|c|}{ Monthly relative frequency of pollen types $\left({ }^{3} R_{F}\right)(\%)$} \\
\hline & & & $\begin{array}{c}\text { Jan/15 } \\
(\mathrm{N}=8)\end{array}$ & $\begin{array}{c}\text { Mar/15 } \\
(\mathrm{N}=5)\end{array}$ \\
\hline \multicolumn{5}{|l|}{ Malpighiaceae } \\
\hline Malpighia emarginata & 16.85 & 8 & 4.54 & 38.02 \\
\hline Stigmaphyllon cavernulosum & 21.72 & 13 & 19.29 & 25.63 \\
\hline Aeschynomene paucifolia & 12.57 & 9 & 13.90 & 10.28 \\
\hline Dioclea grandiflora & 1.18 & 10 & 0.89 & 1.66 \\
\hline \multicolumn{5}{|l|}{ Bignoniaceae } \\
\hline Amphilophium crucigerum & 0.15 & 3 & - & 0.38 \\
\hline
\end{tabular}

${ }^{1} \mathrm{RF}_{\mathrm{t}}=$ Total relative frequency of each pollen type used for larval food in nests built throughout nesting period at PZBGV.

${ }^{2} \mathrm{RF}_{\mathrm{m}}=$ Monthly relative frequency of each pollen type used for larval food in nests built throughout nesting period at PZBGV.

${ }^{3} \mathrm{NN}=$ Number of nests containing each pollen type recorded throughout nesting period. 
and references therein; Rabelo et al., 2015).

Fabaceae was the second most important botanical family found in the larval diet of $C$. analis and C. terminata. We observed a high frequency of occurrence of $A$. paucifolia in the nests of $C$. terminata established at UFBA in February 2015. The species from genus Aeschynomene seem to be an important source of pollen in the larval diet of the Centris species, once the pollen of Aeschynomene martii Benth was found in highest frequencies in C. tarsata nests in the semiarid Caatinga biome (Cruz et al., 2015). On the other hand, considering the two areas studied herein, A. paucifolia was found at low frequencies in some nests of $C$. terminata and C. analis. This data suggest that $A$. paucifolia can be used as a source of nectar, as reported in some studies with C. tarsata and C. trigonoides from Caatinga biome (Dórea et al., 2009; Dórea et al., 2010a; Dórea et al., 2013).

Regarding the pollen types found at low frequencies in the larval food of both bee species, Handroanthus chrysotrichus (Bignoniaceae), Amphilophium crucigerum (Bignoniaceae) and Dioclea grandiflora (Fabaceae) can be considered sources of nectar, whereas Cestrum axillare (Solanaceae), due to its floral morphology (small, long, tubular flowers), may have been used as a source of pollen for both species of Centris. On the other hand, the low frequency of occurrence per nest $(<1 \%)$ of pollen from E. guineenses (Arecaceae), Serjania (Sapindaceae), D. regia (Fabaceae) and $S$. diversifolia (Polygalaceae) makes it difficult to determine the type of resources collected by $C$. analis females.

Concerning the trophic niche of the studied species, the breadth of the niche of $C$. analis at PZBGV differed from that found at UFBA while for $C$. terminata, on the contrary, the breadths of the niches were similar. As reported by Rabelo et al. (2012), such results are directly related to the frequencies of the utilization of each food source by the species.

Niche overlap refers to the utilization of some of the same resource type by two or more species; thus, the greater the number of resources common to both species, the greater the overlap (Abrams, 1980). Some authors have emphasized that the niche overlap between bee species can be influenced by the availability temporal of resources (Carvalho et al., 2013; Santos et al., 2013), by the resource abundance (Aguiar et al., 2013), and by the body size of the individuals exploiting the same resources (Rabelo et al., 2015). In the present study, the low value of the niche overlap between $C$. analis and $C$. terminata at UFBA can be explained to the high frequency of the use of A. paucifolia (Fabaceae) by C. terminata in the nests established in February (2015). On the other hand, the high niche overlap observed at PZBGV between those species can be due to the body size, as reported by Rabelo et al. (2015) for some oil-collecting species.

Centris analis and C. terminata collected resources in several plant species to provision their cells. Similar behaviorwas reported for $C$. analis by Quiroz-Garcia et al. (2001), Roubik \& Villanueva-Gutiérrez (2009) and Santos et al.(2013). Studies on the floral resources used by bees in urban areas can contribute to the establishment of conservation measures and management plans for these important pollinators. Moreover, urban environments are considered important refuges for bee fauna, especially those that nest in preexisting cavities.

\section{Acknowledgments}

The authors are grateful to the Coordenação de Aperfeiçoamento de Pessoal de Nível Superior (CAPES) for providing a scholarship to the first and second authors; Josafá Santos and Taniele Santana of the Laboratório de Bionomia, Biogeografia e Sistemática de Insetos (BIOSIS - UFBA) for assistance in the data collection; Dr. Nádia Roque for the information on the flora of the UFBA and Parque Zoobotânico Getúlio Vargas. The authors also thank the anonymous reviewers that contributed to improving the manuscript.

\section{Authors' contributions}

R LIMA and CA GARÓFALO conceived the study, analyzed the results and contributed to the writing of the manuscript. R LIMA and CT GARCIA performed the field collection of nests. MJ FERREIRA-CALIMAN, MC DÓREA and FAR SANTOS conducted the palynological analysis, analyzed the results and contributed to the writing of the manuscript. FF OLIVEIRA identified the bees and contributed to the writing of the manuscript.

\section{References}

Abrams, P.A. (1980). Some comments on measuring niche overlap. Ecology, 62: 41-49.

Aguiar, C.M.L., Zanella, F.C.V., Martins, C.F. \& Carvalho, C.A.L. (2003). Plantas visitadas por Centris spp. (Hymenoptera: Apidae) na Caatinga para obtenção de recursos florais. Neotropical Entomology, 32: 247-259. doi: 10.1590/S1519566X2003000200009.

Aguiar, C.M.L \& Garófalo, C.A. (2004). Nesting biology of Centris (Hemisiella) tarsata (Hymenoptera, Apidae, Centridini). Revista Brasileira Zoologia, 21: 477-486.

Aguiar, C.M.L., Santos, G.M.M., Martins, C.F.M., Presley, S.J. (2013). Trophic niche breadth and niche overlap in a guild of flower-visiting bees in a Brazilian dry forest. Apidologie, 44: 153-162. doi: 10.1007/s13592-012-0167-4.

Alves-dos-Santos, I., Machado, I.C. \& Gaglianone, M.C. (2007). História Natural das abelhas coletoras de óleo. Oecologia Brasiliensis, 11: 544-557.

Cane, J.H. \& Sipes, S. (2006). Characterizing floral specialization by bees: analytical methods and revised lexicon for oligolecty. In: Waser N.M. \& Ollerton, J. (Eds.), Plantpollinator interactions: from specialization to generalization 
(pp. 99-122). Chicago: University of Chicago Press.

Carvalho, D.M., Aguiar, C.M.L., Santos, G.M.M. (2013).Food niche overlap among neotropical carpenter bees (Hymenoptera: Apidae: Xylocopini) in an agricultural system. Sociobiology, 60: 283-288. doi: 10.13102/sociobiology.v60i3.283-288.

Carvalho, G. M., Roque, N. \& Guedes, M. L. S. (2007). Levantamento das espécies arbóreas da Universidade Federal da Bahia, Salvador, Bahia. Sitientibus. Série Ciências Biológicas, 4: 377-387.

Conder. (1994). Informações básicas dos municípios baianos: Região Metropolitana de Salvador, 267 p.

Coville, R.E., Frankie, G.W. \& Vinson, S.B. (1983). Nests of Centris segregata (Hymenoptera: Anthophoridae) with a review of the nesting habitats of the genus. Journal of the Kansas Entomological Society, 56: 109-122.

Cruz, A. P. A., Dórea, M. C. \& Lima, L. C. L. E. (2015). Pollen types used by Centris (Hemisiella) tarsata Smith (1874) (Hymenoptera, Apidae) in the provisioning of brood cells in an area of Caatinga. Acta Botânica Brasílica, 29: 282284. doi: 10.1590/0102-33062015abb0005.

Dórea, M. da C., Santos, F.A.R., Lima, L.C.L. \& Figueroa, L. (2009). Análise polínica do resíduo pós-emergência de ninhos de Centris tarsata Smith (Hymenoptera: Apidae, Centridini). Neotropical Entomology, 38: 197-202. doi: 10.1590/S1519566X2009000200005.

Dórea, M. da C., Aguiar, C.M.L., Figueroa, L.E.R., Lima e Lima, L.C. \& Dos Santos, F.de A.R. dos. (2010a). Pollen residues in nests of Centris tarsata Smith (Hymenoptera, Apidae, Centridini) in a tropical semiarid area in NE Brazil. Apidologie, 41: 557-567. doi: 10.1051/apido/2010005.

Dórea, M. da C., Aguiar, C. M. L., Figueroa, L.E.R, Lima e Lima, L.C. \& Dos Santos, F.A.R. (2010b). Residual pollen in nests of Centris analis (Hymenoptera, Apidae, Centridini) in an area of Caatinga vegetation from Brazil. Oecologia Australis, 14: 232-237. doi: 10.4257/oeco.2010.1401.13.

Dórea, M. da C., Aguiar, C.M. L., Figueroa, L.E.R,LimaeLima, L.C. \& Dos Santos, F.A.R. (2013). A study of pollen residues in nests of Centris trigonoides Lepeletier (Hymenoptera, Apidae, Centridini) in the Caatinga vegetation, Bahia, Brazil, Grana, 52: 122-128. doi: 10.1080/00173134.2012.745595.

Erdtman, G. (1960). The acetolysis method. A revised description. Svensk Botanisk Tidskrift, 39: 561-564.

Gaglianone, M.C. (2001). Nidificação e forrageamento de Centris (Ptilotopus) scopipesFriese (Hymenoptera, Apidae). Revista Brasileira de Zoologia, 18: 107-117. doi: 10.1590/ S0101-81752001000500008.

Gonçalves, L., Silva, C.I. \& Buschini, M.L.T. (2012).Collection of pollen grains by Centris (Hemisiella) tarsata Smith (Apidae: Centridini): is C. tarsata an oligolectic or polylectic species?
Zoological Studies, 51: 195-203.

Hammer, O., Harper, D.A.T. \& Ryan, P. D. (2001). PAST: Paleontological statistics softwarepackage for education and data analyses. Paleontologia eletrônica 4.

Mendes, F.N. \& Rêgo, M.M.C. (2007). Nidificação de Centris (Hemisiella) tarsata Smith (Hymenoptera, Apidae, Centridini) em ninhos-armadilha no Nordeste do Maranhão, Brasil. Revista Brasileira de Entomologia, 51: 382-388. doi: 10.1590/S008556262007000300017.

Michener, C.D. (2007). The Bees of the World. The John Hopkins University Press, Baltimore, 953 p.

Michener, C.D. \& R.B. Lange. (1958). Observation on the ethology of Neotropical anthophoridae bees (Hymenoptera: Apoidea). University of Kansas Science Bulletin, 39: 69-96.

Melo, G. A. R. et al. (2014). Polinização e polinizadores de maracujá no Paraná. In: Yamamoto, M.; Oliveira, P. E.; Gaglianone, M. C. Uso sustentável e restauração da diversidade dos polinizadores autóctones na agricultura e nos ecossistemas relacionados: Planos de manejo. Rio de Janeiro: Funbio, p. 207-253.

Mello, M.A.R.; E.L.S. Bezerra \& I.C. Machado (2013). Functional roles of Centridini oil bees and Malpighiaceae oil flowers in biome-wide pollination networks. Biotropica, 45: 45-53. doi: 10.1111/j.1744-7429.2012.00899.x

Moure, J. S., Melo, G.A.R. \& Vivallo, F. (2012). Centridini Cockerell \& Cockerell, 1901. In Moure, J. S., Urban, D. \&Melo, G. A. R. (Orgs). Catalogue of Bees (Hymenoptera, Apoidea) in the Neotropical Region - online version. Available at http://www. moure.cria.org.br/catalogue. (Accesseddate:7 August, 2016).

Neff, J.L. \& Simpson, B.B. (1981). Oil-colleting structures in the Anthophoridae (Hymenoptera): Morphology, function, and use in systematics. Journal of the Kansas Entomological Society, 54: 95-123.

Oliveira, R. \& Schlindwein, C. (2009). Searching for a manageable pollinator for acerola orchards: the solitary oil-collecting bee Centris analis (Hymenoptera: Apidae: Centridini). Journal of Economic Entomology, 102: 265-273. doi: 10.1603/029.102.0136.

Pianka, E. R. (1973). The structure of lizard communities. Annual Review of Ecology and Systematics, 4: 53-74.

Pielou, E.C. (1966). An introduction to mathematical ecology. New York, John Wiley \& Sons, 286 p.

Pielou, E.C. (1975). Ecological diversity. New York, John Wiley \& Sons, $165 \mathrm{p}$.

Quiroz-Garcia, D. L., Martinez-Hernandez, E., Palacios-Chavez, R. \& Galindo-Miranda, N. E. (2001). Nest provisions and pollen foraging in three species of solitary bees (Hymenoptera: Apidae) from Jalisco, México. Journal of the Kansas Entomological Society, 74: 61-69. 
Quiroz-Garcia, D.L., de la Arreguin-Sánchez, M.L. (2006). Resource utilization by Centris flavofasciata Friese (Hymenoptera: Apidae) in Jalisco, México. Journal of the Kansas Entomological Society, 79: 249-253. doi: 10.2317/0502.15.1.

Rabelo, L.S., Vilhena, A.M.G.F., Bastos, E.M.A.F. \& Augusto, S.C. (2012). Larval food sources of Centris (Heterocentris) analis (Fabricius, 1804) (Hymenoptera, Apidae), an oil-collecting bee. Journal of Natural History, 46: 1129-1140. doi: 10.1080/00222933.2011.651798.

Rabelo, L.S., Vilhena, A.M.G.F., Bastos, E.M.A.F., Aguiar, C.L. \& Augusto, S.C. (2015). Oil-collecting bee-flower interaction network: do bee size and anther type influence the use of pollen sources? Apidologie, 46: 465-477. doi:10.1007/ s13592-014-0336-8.

Ramos, M., Mendes, F., Albuquerque, P. \& Rêgo, M. (2007). Nidificação e forrageamento de Centris (Ptilotopus) maranhensis Ducke (Hymenoptera, Apidae, Centridini). Revista Brasileira de Zoologia, 24: 1006-1010. doi: 10.1590/ S0101-81752007000400017.

Ramalho, M. \& Silva, M. (2002). Flora oleífera e sua guilda de abelhas em uma comunidade de restinga tropical. Sitientibus série Ciências Biológicas, 2: 34-43.

R Development Core Team. (2011). A language and environment for statistical computing. R Foundation for Statistical Computing, Vienna, Austria. Retrieved from: URL http://www.R-project.org.

Rêgo, M.M.C., Albuquerque, P.M.C., Ramos, M.C.\& Carreira, L. M. (2006). Aspectos da Biologia de Nidificação de Centris flavifrons (Friese) (Hymenoptera: Apidae, Centridini), um dos principais polinizadores do Murici (Byrsonima crassifolia L. Kunth, Malpighiaceae), no Maranhão. Neotropical Entomology, 35: 579-587. doi: 10.1590/S1519-566X2006000500003.

Ribeiro, E.K.M.D., Rêgo, M.M.C. \& Machado, I.C.S. (2008). Cargas polínicas de abelhas polinizadoras de Byrsonima chrysophylla Kunth. (Malpighiaceae): Fidelidade e fontes alternativas de recursos florais. Acta Botânica Brasílica, 22: 165-171.
Roubik, D. \& Villanueva-Gutiérrez, R. (2009). Invasive Africanized honey bee impact on native solitary bees: a pollen resource and trap nest analysis. Biological Journal of the Linnean Society, 98: 152-160. doi: 10.1111/j.10958312.2009.01275.x.

Santos, R.M., Aguiar C.M.L., Dórea M.C., Almeida, G.F., Santos, F.A.R. \& Augusto, S.C. (2013). The larval provisions of the pollinator Centris analis pollen espectroand tropic niche breadt in agroecossistem. Apidologie, 44: 630-641. doi: 10.1007/s13592-013-0211-z.

Silva ,C.I, Arista, M., Ortiz, P.L., Bauermann, S.G, Evaldt, A.C.P. \& Oliveira, P.E. (2010). Catálogo polínico: palinologia aplicada em estudos de conservação de abelhas do gênero Xylocopa no Triângulo Mineiro. EDUFU, Uberlândia.

Vergeron, P. (1964). Interprétation statistique des résultats en matière d'analyse pollinique des miels. Annales de 1'Abeille, 7: 349-364.

Vieira-de-Jesus, M.B. \& Garófalo, C.A. (2000). Nesting behaviour of Centris (Heterocentris) analis (Fabricius) in southeastern Brazil (Hymenoptera, Apidae, Centridini). Apidologie, 31: 503-515. doi: 10.1051/apido:2000142.

Vilhena, A.M.G.F. \& Augusto, S.C. (2007). Polinizadores da aceroleira Malpighia emarginata DC (Malpighiaceae) em área de cerrado no Triângulo Mineiro. Bioscience Journal, 23: 14-23.

Vinson, S.B. \& Frankie, G.W. (2000). Nest selection, usurpation, and a function for the nest entrance plug of Centris bicornuta (Hymenoptera: Apidae). Annals of the Entomological Society of America, 93: 254-260. doi:10.1603/0013-8746(2000)093\%5B0 254:NSUAAF\%5D2.0.CO\%3B2.

Vogel, S. (1974). Ölblumen und ölsammelnde Bienen. Tropische und Subtropische Pflanzenwelt 7:285-547.

Zar, J.H. (1984). Biostatistical Analysis. Prentice Hall, New Jersey, USA, 718 p. 